Technische Universität Berlin, Institut für Soziologie

DOI: https://doi.org/10.46630/gsoc.23.2019.05

\title{
УВОД У КОМУНИКАТИВНУ КОНСТРУКЦИЈУ СТВАРНОСТИ ${ }^{2}$
}

Убрзо након што су Бергер и Лукман (Berger \& Luckmann) објавили књигу Друштвена конструкиија стварности, филозофи Камла и Лоренцен су својим делом Логичка пропедевтика, објављеним 1967 (Kamlah \& Lorenzen 1994), покушали да усмере филозофију ка новом правцу. Књига је била један од основних извора за оно што је касније названо „методолошким конструктивизмом“", који се бави питањем где и како почиње логика и, са њом, рационално размишљање кроз употребу језика. Аутори су сматрали да је решење овог „проблема почетка“ једноставно: то је чин реферирања или, прецизније, показивања (pointing/Zeigens). По њиховом мишљењу, показивање је телесни процес „предикације“. Предикација, у смислу додељивања атрибута објекту, захтева да реферирамо на објекат. Деиктичким чином показивања реферира се на нешто у свету на начин који одговара предикацији - без језика. На овој основи су Камла и Лоренцен потом развили систематску и формалну логику.

Показивање ће и у овој књизи стално да служи као пример онога што називамо комуникативним делањем. Пошто показивање прстом парадигматично илуструје да телом можемо да направимо јасну референцу и то без употребе језика, оно показује и телесне аспекте комуникације. Човеку чак ни не треба језик да би био логичан и рационалан; телесни чин показивања је довољан као „практичан“ учинак логике. На основу тог чина може да се изведе логички систем који је општи у истој мери као и способност показивања.

Изгледа да је покушај да се окарактерише логика, рационално размишљање, па чак и наука, без ослањања на језик, проблем који није често обрађиван. Са социолошког становишта постоје добри разлози да се језик не посматра као неутрално средство за анализу друштва јер се језици међусобно разликују и разликују се у зависности од културе и друштва. Уколико се крене од одређеног језика како би се пронашла општа теорија логике или било који други аналитички систем, лако се може упасти у замку етноцентричности, другим речима, у „поглед на свет“ уграђен у сваки језик.

\footnotetext{
${ }^{1}$ hubert.knoblauch@tu-berlin.de

${ }^{2}$ Ово је прво поглавље књиге која је објављена на немачком као Kommunikative Konstruktion der Wirklichkeit (Wiesbaden: Springer VS); књига је објављена и на енглеском језику (Communicative Construction of Reality) у издању Routledge (London 2019). Захваљујемо се аутору за енглеску верзију текста, на основу које је и урађен овај превод.
} 
Са друге стране, логика представља имплицитну рационалност сваког људског размишљања и делања, а као што и показивање то доказује, та ра-

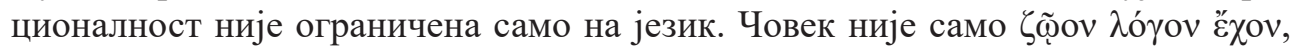
створење које има језик. Где можемо, питамо се, да пронађемо овај облик рационалности ако не у језику? Одговор можемо да (про)нађемо у Камловој и Лоренценовој анализи показивања. Показивање није усамљени чин којим се један актер или мислилац суочава са светом, идентификујући објекте помоћу тог чина. У ствари, чин показивања не подразумева само да постоји нешто на шта се показује, већ и да постоји неко други ко уочава показивање. Показивање је основни друштвени процес. Показивање има смисла само унутар друштвеног односа: ако субјекат показује нешто другом субјекту.

Увид Камле и Лоренцена о темељној друштвености показивања је од раније присутан у социологији, социологији знања и (социолошким) проучавањима науке, али не и у филозофији. ${ }^{3}$ Комуникативни чин показивања јасно указује на то у којој мери су знање и размишљање друштвено условљени: показивање се заснива на односу између најмање два субјекта који реферирају на трећи елемент тако да он за њих има смисла. Ако сматрамо да је показивање основни чин, морамо узети у обзир и друштвеност која се налази у његовој основи. Најопштија теза ове књиге је да су комуникативна делања, као што је показивање, основни друштвени процес којим се друштво и његова стварност конструишу.

\section{1. Наука и теорија}

Данас се понекад тврди да покушај тражења „основе“ друштвеног подсећа на облик „теоријског фундаментализма“ који игнорише разлике и различитости друштвене стварности (видети Marchart 2013). ${ }^{4}$ Настојање да се друштвеност подведе под заједнички именилац који представља западни, етноцентрични, рационални „поредак“ је оправдано доведено у питање јер су се и друге „рационалности“, поред западно-научних, посебно током последњих деценија помериле ка центру све глобализованије свести о интелектуалним традицијама: чини се да тај искорак ка модерности обухвата афричке, азијске, црначке и латиноамеричке карактеристике, па чак и просветитељски аутори признају да су религије рационално допринеле „постсекуларном добу“ (Eisenstadt 2002; Habermas \& Ratzinger 2006). Али управо та све већа разноликост захтева да покушамо да трагамо за заједничким особинама. Зато овде почињемо од тако једноставног геста као што је показивање, који сви свакодневно користимо и узимамо здраво-за-готово.

Чињеница да се овом заједничком именитељу приближавамо помоћу аналитичких алатки друштвених наука не значи да треба искључити друге култур-

\footnotetext{
${ }^{3}$ У филозофији, „социјална епистемологија“ је недавно усвојила ову идеју друштвености.

${ }^{4}$ Чак и Маршарт (Marchart 2013: 13) признаје да „основе друштвености“ не нестају.
} 
не перспективе. Иако смо свесни да се друштвене науке заснивају на традицији и историји које су под западним утицајем, оне никако не искључују перспективу „других“ или чак „странаца“, чега се феминистички, постколонијални и постхуманистички аутори оправдано плаше. Међутим, као што су њихови страхови од унификације и преурањеног уопштавања утемељени, ови аутори своје аргументе заснивају и на некој врсти научног језика, али чак ни најдубље поштовање различитих научних култура не може да избегне оно што Чакрабарти назива „постколонијалном дилемом“:

Свет идеја који се (по)јавио у доба европске експанзије и колонизације изгледа колико неизбежан, толико и неодговарајући за описивање и анализирање сопствене (незападне) историје и друштва. (Chakrabarty 2010: 11f)

Иако наука остаје несавршена, њена комуникација постаје све глобалнија и разноврснија, тако да омогућава методичку рефлексију ограничености сопствене перспективе. Западни утицај науке није неминован - он је сам по себи друштвено-историјски резултат комуникативних делања и може да се рефлектује, допуни и трансформише укључивањем других перспектива. Сходно томе, различитост субјективних позиција повезаних са полом, родом, друштвеним положајем или културом може да се објасни тако да се „свет живота“ више не схвата као универзална, већ релациона, релативна и комуникативна категорија.

Овај корак ка релативизацији води друштвену теорију у правцу онога што Бамбра (Bhambra 2014: 215) назива „повезаним социологијама“: социологија следи „етику друштвеног конструктивизма“ “ која не води ка универзализацији и која сматра да су норме науке саме по себи резултат друштвене и (посебно у науци) неопходне комуникативне конструкције. Ова врста релационе социологије дистанцира се од фундаментализма универзалистичких теорија, али се не покорава релативизму. Наука као што је социологија стално се мења, али ипак има нормативно језгро у комуникативном делању - у било ком тренутку тврдња о ваљаности истине може да буде критички преиспитивана, промењена или одбачена. ${ }^{5}$ Наука је можда једина институција у друштву у којој Хабермасова потреба за неауторитарном комуникацијом није само идеал, већ норма која се може захтевати у сваком чину производње знања (било да се ради о „стручном жаргону“, предавањима или састанцима ${ }^{6}$ - без обзира на културу, религију или политички систем. Пошто више не тражимо истину на наиван начин и не верујемо у постепено приближавање правој истини, способност да преиспитујемо наше методе, појмове и форме постаје један од најбитнијих процедуралних критеријума за научност. ${ }^{7}$

Пошто овај критички став не произлази из јачине стабилних непромењи-

\footnotetext{
${ }^{5}$ Мертон (Merton 1949) ову карактеристику науке назива „организованим скептицизмом“.

6 То укључује начине на које „опажања“, на пример, помоћу микроскопа, постају налази. Ово је илустровано у анализи Латура и Вулгара (Latour \& Woolgar 1979), студији научно-истраживачког пројекта који је касније награђен Нобеловом наградом.
}

${ }^{7}$ Критика стога увек подразумева рефлексивну самокритику посматрања, као што је, на пример, захтевао Бурдије (Bourdieu 2001). 
вих аксиома, он је нужно конструктивистички. Увек морамо да узмемо у обзир да наше претпоставке могу да буду погрешне, нелогичне или емпиријски неутемељене. Уместо преурањеног усвајања онтолошких исказа, наука је оријентисана на методе којима долази до својих исказа и којима их потврђује и оповргава. ${ }^{8}$ Под методама подразумевамо одређивање начина на који се стварају резултати и то тако да други могу да их разумеју - како би неко могао да спроведе слична опажања, тумачења и закључивања - и где сваки од тих начина зависи од друштвених, променљивих верзија интерсубјективности, методологије и ваљаности. Наука је друштвени производ. Штавише, производња знања и критика тог знања, као и рефлексија и дискусија о знању у великој мери се остварују кроз комуникативна делања и зависе од онога што називамо ,језиком науке“".

\section{2. Научни језик и дискурс}

Баш као што је методологија срж науке (а техника истраживања врста материјализоване методологије), покушаји да се помоћу чистог или радикалног конструктивизма дође до „предмета“ науке помоћу метода истраживања лако могу да заврше у релативизму (упор. Meidl 2009). Насупрот таквим чистим или радикалним конструктивистичким приступима, комуникативни и социјални конструктивистички приступи полазе од тога да конструкција не почиње увек $a b$ ovo (из почетка), већ се одвија у већ конструисаној стварности. Наука не мора и не може да поново открије своје методе и језик, већ се ослања на већ успостављене методе, рутинске праксе и језик у већ постојећим „универзумима дискурса“ (Mead). Научне дисциплине карактеришу одређени језици, универзуми дискурса и заједнице. Штавише, у науци језик постаје рутинизован, формалан и реторичан, али научни језик дугује конструисани карактер свом специфичном, вештачком стилу. Само зато што не желимо да комуникативно делање сведемо само на језик, треба да додамо да језик науке и њени дискурси увек, и све више током последњих деценија, зависе од телесних перформанси, од визуелизације и од моделовања. ${ }^{9}$

Када говоримо о специфичним универзима дискурса у којима се стварају научни искази, морамо да прихватимо све већу диференцијацију и фрагментацију специјализованог знања, посебних дискурса и одређених заједница дискурса, на пример, дисциплина, поља истраживања и парадигми. ${ }^{10}$ Ови уни-

\footnotetext{
${ }^{8}$ Као и у социологији знања, наука се бави оним што се данас назива „критичким онтологијама“, тј. оним што актери сматрају стварношћу.

${ }^{9}$ Увелико се расправља о огромном утицају који визуализација има на откриће научне истине. Све већа улога презентација у науци, на пример помоћу PowerPoint-a, доводи до све већег значаја тела (Knoblauch 2013).

10 Одбацивање ове традиције аутоматски води до „иновације“, уз ризик да та иновација буде једноставно преименовање и поново процењивање онога што је већ познато. Овај проблем је посебно изражен у друштвеним и хуманистичким наукама, које свој недостатак континуитета
} 
верзуми дискурса разликују се од свакодневног језика кроз „,офистицирану семантику“ (Luhmann 1980) повезану са њиховом специјализованом структуром знања. Структура ових дискурса се све више одражава у структури наука, при чему свака тврди да има своје предмете и, сходно томе, сопствена поља истраживања.

Диференцијација дискурса је један од разлога због ког актери изван ових области имају ограничено разумевање науке. То је зато што, чак и ако понекад треба „показати“ на објекте нашег истраживања, предмети различитих научних дисциплина су ретко кад једноставни. Напротив, они се стварају у контексту научног дискурса, а сваки се односи на посебне теме и проблеме истраживања. Цену ове специјализације наука плаћа кроз одређени ниво неразумљивости, али само на тај начин она може да примењује своје методе и омогући да њене тврдње буду подвргнуте посебним критикама. Међутим, ово се односи само на дискурсе унутар науке, а који су намењени заједници научника, као и ова књига. Неразумљивост специјализованих наука је критикована у бројним интердисциплинарним приступима којима се захтева коришћење много шире и општије терминологије у дискурсима. Штавише, захтеви политичких, економских и других јавних институција и њихово финансирање истраживања утичу на науку тако што она усваја категорије из политичких, економских и других дискурса, на пример, религије. Такође, чињеница да су и универзитети део образовног система указује на снажну везу између научног и свакодневног знања, на пример, у настави. Поред тога, популаризација је одувек била важна за науку. На крају, друштво знања са пуним правом тражи од науке да допринесе његовој производњи знања (Burawoy 2005). Међутим, наука би сама себе порицала уколико би сопствене дефиниције предмета и одговарајуће дискурсе и истраживачке проблеме заменила јавним говором или политичком и економском агендом.

\section{3. Теорија}

Посебна осетљивост науке на критику јавља се због њене потребе да преиспитује сопствене емпиријске налазе, методе којима се до њих долази и, на крају, теоријске концепте помоћу којих се они разумеју и објашњавају. Концепте и њихову повезаност називамо теоријама, док се методологија бави питањем онога што сматрамо „објашњењем“, „разумевањем“, „уверљивошћу“ и свим другим циљевима којима тежимо. Методологија преиспитује, дефинише и потврђује ове циљеве и начине на које се они постижу, односно методе којима је наука повезана са својим предметом. Дискусија о теоријским терминима је самим тим специфичан задатак саме научне критике. Будући да већина наука

плаћају одговарајућим променама у доприносу знању. Стога, захтев да се узме у обзир „најсавременије истраживање“ не служи само за превазилажење поперовске идеје о „напретку знања“, већ просто да се избегне обављање већ готовог посла. 
дефинише своје концепте (у оквиру одређених теоријских дискурса) својим природним језицима и граматикама, својом лексиком и својом семантиком, формулисање теорије представља одређену врсту изазова. Ови изазови су још већи ако се емпиријски предмети науке не могу прецизно разликовати помоћу егзактних метода, као што је то често случај у друштвеним и наукама о култури (Kulturwissenschaften). Тачно је да овај проблем може да покуша да се реши фигуративним, метафоричким језиком, али такав приступ често прелази у домен уметности и књижевности, стварајући осећај естетског уживања, али истовремено доводећи у питање саму научност таквог приступа. Због тога што теорију формулишемо у свакодневном природном језику, и све док чинимо тако, захтев за концептуалном прецизношћу остаје пресудан. Потребно је, дакле, да наше концепте упоређујемо са концептима из других теоријских дискурса који се баве истом тематиком, превасходно друштвеношћу. Ова концептуална поређења могу повремено и у извесној мери да делују заморно, али су она неопходна да би се постигао одређени степен прецизности. Да бисмо то постигли, упоређиваћемо концепте једне са другима, као и обележја која произлазе из тих концепата (односно њихову „екстензионалност“, као и њихову „интенционалност“, као што су описали Ханапел и Меленк (Hannappel \& Melenk 1979). ${ }^{11}$

Структура ове књиге грађена је на основу следеће логике: полази се од неколико врло општих (и у великој мери недовршених) темељних концепата из којих се онда изводе конкретнији термини. Такав приступ значи да смо на основу (врло бројне) консултоване литературе у овој области истраживања, аналитички издвојили одређене концепте и даље их развијали у правцу једне теорије. Циљ формирања те теорије је кохерентно и доследно међусобно повезивање тих концепата и то на начин којим теоријско објашњење произилази из повезаности категорија, чиме се, у суштини, одговара на питање шта је друштвено и како се друштвени феномени могу повезати. Методолошки, теорија не полази од самих аксиома, већ је делимично заснована на емпиријском истраживању што ће бити скицирано у наставку. ${ }^{12}$

Што се наслова ове књиге тиче, треба нагласити да са̂м теоријски аргумент који је овде представљен не треба сматрати „конструкцијом“. Конституисање појмова није исто што и конструкција стварности, јер дедукција појмова не значи повезивање појмова емпиријски, већ логички. Са друге стране, ни друштвена нити комуникативна конструкција стварности не подлежу емпиријски семантичким приавилима друштвене теорије, већ зависе од процеса које формулишемо у теорији друштва.

Ово упозорење указује на различите нивое конституисања теорије, од којих сваки има различит степен општости. ${ }^{13}$ Разликујемо три сукцесивна и,

\footnotetext{
${ }^{11}$ Међутим, користићемо појам „аспект“ да означимо атрибуте концепата које не приписујемо њиховој „супстанци“, како би то класична метафизика назвала, већ на методологији и њеној аналитичкој перспективи.

${ }^{12}$ Стварање теорије у извесној мери подсећа на методу аналитичке индукције коју је осмислио Знањецки (Znaniecki), а коју је на узоран начин примењивао Кац (Katz 2001).

${ }^{13}$ Мертон (Merton 1949) реферише на теорије високог степена асптракције и „теорије средњег 
истовремено, независна нивоа теорије. Пошто разлика између друштвених теорија, социолошке теорије и дијагноза друштвеног чини и главну структуру ове књиге, требало би укратко описати ова три концепта.

\section{(а) Друштвена теорија}

Када говоримо о комуникативној конструкцији стварности у овој књизи, говоримо о веома широко прихваћеном „друштвено-феноменолошком“ или „друштвено-конструктивистичком“ приступу теоријске социологије (Knoblauch \& Wilke 2016). Овај приступ се односи на дискурзивну тему, која се конвенционално назива „социолошка теорија“ и обухвата више или мање институционализовано поље социолошког истраживања, као што су историја социологије и социолошке идеје, теоријска поређења итд. ${ }^{14} \mathrm{C}$ обзиром да се дискурс ,друштвеног конструктивизма“ проширио изван социолошке теорије и на „друштвене теорије“, ми ћемо и теорију комуникативне конструкције разматрати у том ширем оквиру, јер он обухвата опште и темељне концепте друштвених наука и наука о култури. На тој основи друштвене теорије затим градимо теорије друштва. Теорије друштва дефинишу предмет емпиријске социологије, политикологије и економије. Коначно, концепт дијагнозе односи се на проучавање скорашњих промена у савременим друштвима. Када говоримо о дискурсу о друштвеној конструкцији, требало би укратко објаснити и однос између „дијагнозе друштвеног“, „,социолошке теорије“ и ,друштвене теорије“, а који дефинише сам предмет друштвених наука.

Ако пратимо Ендресову (Endreß 2002) реконструкцију генезе друштвене теорије у социјалном научном дискурсу, онда видимо да се појам јавља у енглеском говорном окружењу као концептуална екстензија друштвено-филозофске „социјалне мисли“ ка интердисциплинарној „друштвеној теорији“, замењујући оно што се некада називало „социолошка теорија“. Ендрес тврди да је концепт „друштвене теорије“ у друштвеним наукама заменио „социолошку теорију“ у оквиру социологије у радовима Гиденса (Giddens) и Колмана (Coleman). Друштвену теорију различито користе различити научници, али је концепт заменио социолошку теорију, која се бави питањем конституције друштвеног.

Овај прелаз са социолошке на друштвену теорију има и институционални аспект, као што је то приметио Гиденс, који каже:

Позадину ове књиге чини низ значајних помака у друштвеним наукама током протеклих петнаест година. У великој мери они су били део друштвене теорије, а посебно су утицали на најозлоглашенију и најпровокативнију друштвену науку, социологију. (Giddens 1984, xiii)

обима“ као што су теорије друштвене перцепције, друштвене контроле и структуре друштвених институција.

${ }^{14}$ Социолошка теорија постала је скоро канонизовани предмет академске наставе. Студије различитих теорија често их сматрају другачијим парадигмама или „мулти-парадигматским“ (упор. Seidman 2004). Будући да се многе од ових теорија баве различитим аналитичким аспектима исте теме (делање, интеракција, комуникација), оне би требало да се сматрају допунским на начин који је објашњен разним унакрсним референцама у овој књизи. 
Дакле, могуће је да је на екстензију термина друштвена теорија утицала чињеница да су од седамдесетих година 20. века, посебно у Уједињеном Краљевству, социологија и већина социолошке теорије изгубиле свој легитимитет. Како је Маргарет Тачер изјавила да „не постоји таква ствар као друштво“, чинило се корисним да се лексички пређе на проучавање друштвеног. Овај потез је такође указао на одвајање од „социологије“ тако да је појам друштвене теорије добио много шире значење, означавајући епистемолошко поље које је поставило темеље за социолошку теорију. Из тог разлога, питањем друштвеног се све више баве и друге дисциплине. Истовремено „друштвена теорија“ је избегла да се сведе на социјалну филозофију, дисциплину која ретко покушава да се повеже са другим дисциплинама које емпиријски проучавају друштвеност. У ствари, приступи друштвеној теорији могу се наћи, на пример, у антропологији, у проучавањима образовања и религије, као и у различитим трансдисциплинарним контекстима, попут родних студија, постколонијалних студија и, наравно, у теоријама о дискурсу.

Релевантност друштвене теорије која се након тога проширила увећала је њен емпиријски опсег, али то никако није довело до прецизнијег аналитичког разумевања речи „друштвено“ и „друштвеност“. То је сасвим разумљиво јер је друштвена теорија постала заједнички именитељ, не само за друштвене науке, већ и за друге дисциплине. Чак и на нивоу уџбеника, термин друштвена теорија се повремено користи искључиво за дискусију о теоријама културе (Elliott 2009). Колико год да је овај појам постао широк и дифузан, он се ипак може посматрати као концептуална категорија у основи најразличитијих друштвених и културолошких наука или хуманистичких дисциплина (које се овде, наравно, такмиче са све распрострањенијим тврдњама „теорије културе“).

Чак и претпоставка да друштвена теорија има јасно дефинисану границу са природним, техничким и биолошким наукама више не важи јер се истраживања о вештачкој интелигенцији, неуро-информатици и роботици експлицитно баве проблемима друштвене теорије (нпр. „социјалним мозгом“, „дистрибуираном когницијом“, „,емоционалном роботиком“, „заокретом у превођењу“) $)^{15 *}$. Управо зато што друштвеност повезујемо са телом и његовим деловањем, комуникацију животиња, као и међуљудску комуникацију треба сматрати друштвеним: симбиоза, паразитизам и коменсализам су облици друштвености, као што је и формирање заједница инсеката. ${ }^{16}$ Код мрава, комуникација која чини друштвеност може да обухвата транспорт који обављају појединачни инсекти, али комуникација може да буде испуњена буком, мирисима или добро познатим плесом, код пчела (Buschinger 1985).

Колико год да тежимо општој теорији друштвеног, не можемо много тога општег да тврдимо у вези са различитим врстама. Можда бисмо могли да се

\footnotetext{
${ }^{15}$ У оринигиналу: “Social Brain”, “Distributed Cognition”, “Emotional Robotics”, “Translational Turn” (ирим. ирев.)

16 У свим овим случајевима друштвеност је директно повезана са комуникацијом. У случају симбиозе између вишећелијских организама, комуникација може бити телесна, као што су метаболички процеси или фотосинтеза (Görtz 1988).
} 
окренемо антрополошким поређењима. Међутим, већина етолошких и биолошких приступа не може да се користити јер занемарују посебност људске друштвености. У овим приступима комуникативно делање је сведено на биолошке процесе, а питања која се тичу начина на који ови процеси могу бити прецизно описани, схваћени и посредовани остају отворена. Чак и ако у оквиру наука о животу данас примећујемо приближавање ономе што називамо друштвеном теоријом (на пример, са открићем „личности“ животиња у биологији), ипак не можемо да премостимо јаз који друштвене науке дели од природних.

Филозофска антропологија је дуго била изузетак и на њу ћемо се осврнути у неколико наврата. Међутим, приступ филозофске антропологије отвара два проблема. Са једне стране, она се већ појмовно поистовећује са „,антропологијом“, фокусирајући се много више на дефинисање разлика на границама људског, а мање на транзиције ка другим врстама и заједничке карактеристике између њих. Са друге стране, већина систематских радова из филозофске антропологије написана је у прошлом веку и они су углавном потицали из немачког говорног подручја. Референце на најновија истраживања у природним наукама присутне су у само неколико приступа, као што је Линдеманова (Lindemann 2002) студија о интензивној нези. По мом мишљењу, даљи развој филозофског антрополошког приступа у односу на емпиријска научна истраживања још није остварен. Према томе, не можемо да се ослањамо на савремену, антрополошку базу јер она ни не постоји. Размотрићемо ову ситуацију методолошки, уз минимално ослањање на тврдње које се тичу антрополошких претпоставки комуникативног делања, али не оспоравајући њихов значај и емпиријску релевантност.

Иако се нећемо ослањати на антрополошке претпоставке које су важиле у друштвеним теоријама од времена просветитељства, нећемо прихватити ни претпоставке „симетричне“ друштвене теорије о томе да друштвеност свих врста треба третирати на исти начин. Само зато што у овом тренутку комуницирамо једни са другима помоћу читања и писања, што је способност својствена само људима, морамо да се сложимо да је наша перспектва нужно „људска“. Дакле, наша друштвена теорија нужно има људску страну која je „,асиметрична“, како каже Латур (Latour 2001), или, да цитирамо Бергера (Berger 1971), има „хуманистичку перспективу“. Ми се бавимо људском комуникацијом, то јест, облицима комуникативног делања које је присутно међу људима - али то не сме да буде ограничено само на људе. Шимпанзе очигледно могу да учествују у овој комуникацији, на пример, да науче да показују; пси такође могу да разумеју комуникативно делање и, вероватно ће роботи ускоро моћи да комуницирају рутински на начин који је сличан људском комуникативном делању јер се већ тестирају за употребу код пацијената са деменцијом (Beer et al. 2015).

Ова врста комуникативног делања чини срж наше друштвене теорије јер је оно основни процес људске друштвености. Оно означава телесне радње које су оријентисане према другима и које добијају значење кроз процес објекти- 
вације, па их стога могу разумети све стране у процесу комуникације. Услед такве реципрочности, комуникативно делање је уграђено у однос и може, када пређе у рутину, да се обавља и као самостална радња, на пример мисао. Или другим речима, оно је субјективирано. Понављањем, комуникативно делање прераста у структуре и институције, може да обухвата материјалне објекте, медије и технологије и постаје ствар конвенције, значења, а тиме и културе.

Друштвена теорија дефинише предмет друштвених и наука о култури у свим њиховим варијететима. Будући да она повезује и друштвеност са предметима других наука, попут природе или живота, она је део теорије науке. Дефинише оно што желимо да опишемо, анализирамо и објаснимо у оквиру одређене научне дисциплине. Друштвена теорија, међутим, не објашњава само специфичности друштвених феномена у њиховим културним и историјским облицима. Она такође дефинише предмет на општи начин тако да може да се обрађује у различитим дисциплинама, као што су социологија, политикологија или комуникологија, на свој посебан начин. Овај ниво општости објашњава зашто друштвену теорију нужно карактерише висок степен апстракције. Друштвена теорија мора да буде апстрактна јер њени концепти обухватају широк спектар емпиријских феномена и зато што мора да обухвата многе различите дисциплине, пружајући заједнички језик за све оне који истражују идентификоване објекте. Коначно, изабрани концепти друштвене теорије треба да буду темељни и да нам омогуће да размишљамо о научној теорији, методологији и емпиријским методама у друштвеним, природним и наукама о култури. ${ }^{17}$

Друштвене теорије не могу бити емпиријски поткрепљене. Емпиријска истраживања могу у најбољем случају подржати њихову уверљивост. ${ }^{18}$ Због тога је чест критеријум квалитета (теоријских) истраживања њихова корисност за емпиријска истраживања (која, међутим, не треба помешати са све чешћом тенденцијом једноставног илустровања теорија и несистематском „теоретизацијијом“ емпиријских истраживања). Друштвене теорије се могу окарактерисати и тиме колико добро, брзо или лако нам омогућавају да формулишемо објашњења. Коначно, степен до ког друштвене теорије систематски повезују своје категорије или се повезују са другим теоријским приступима може бити додатни критеријум њиховог квалитета. У ствари, теорија комуникативне конструкције изнета овде заснива се на строгим емпиријским истраживањима. Она покушава да развије систематску теорију која допушта објашњења и наглашава односе са другим теоријама, али и разлике између њих.

\section{(б) Социолошка теорија}

Друштвена теорија представља основу јер дефинише или разјашњава појам друштвености који је предмет друштвених наука. Полазећи од експли-

\footnotetext{
${ }^{17}$ То се постиже изучавањем науке и технологије, али без разјашњеног односа између социологије знања и филозофије науке.

${ }^{18}$ Сасвим је могуће гледати емпиријске податке и доделити их теоријским концептима; „постквалитативни теоретизам“ користи овај метод као абдуктивно истраживање података, примењујући углавном концепте постструктуралистичких теорија на податке (уп. Keller 2014).
} 
цитних претпоставки и аксиома онога што друштвеност подразумева, друштвена теорија логично изводи додатне категорије које допуњују основни концепт друштвености. На пример, говоримо о аксиоматској, субјективистичкој основи друштвеног у феноменолошком дискурсу, износимо критику о њој и бирамо релациони приступ, изведен из аксиома и критика. Теорије, као што су теорија дискурса или теорија праксе, неће се разматрати на овом основном нивоу, јер не дефинишу друштвеност, већ је претпостављају. Сматрамо, дакле, да оне представљају део теорије друштва или, како их ми називамо, социолошке теорије.

Користећи појам социолошке теорије на овај начин ослањамо се на предлог Линдемана (Lindemann 2014: 328ff). ${ }^{19}$ Линдеман одређује социолошку теорију као „теорију конкретне историјске друштвене формације“ (Lindemann 2009: 33). Социолошка теорија се односи на анализе модерног друштва, на пример Вебера, Диркема и Парсонса. Док друштвена теорија означава оно што је друштвено на апстрактан, општи и емпиријски неодређен начин и ограничава га као предмет низа друштвених и културних наука, категорије социолошке теорије служе за одређивање карактеристика емпиријских друштава, као и за идентификовање сличности и разлика између различитих друштава, која су предмет социологије и етнологије. На пример, социолошку анализу модерног друштва карактерише углавном хоризонтална диференцијација њених институционалних поља и егалитарне легитимације, за разлику од премодерних друштава која се састоје од хијерархијских институционалних поредака. Социолошка теорија описује оне аспекте друштва који карактеришу друштво у целини кроз различите колективитете који га сачињавају. Различите „теорије средњег обима“" чине део социолошке теорије јер истраживачи усмеравају своју пажњу на одређене аспекте друштва, као што је улога знања или интеракција. Теорије средњег обима реферишу на посебне области, поља или системе, који изгледају мање или више јасно дефинисани од стране актера или истраживача, као што су кланови, старосне групе, касте, друштвене класе или организације.

Када окарактеришемо друштва као велика, не ограничавамо их само на национална друштва. Теорија друштва бави се разним врстама великих формација, од глобалног светског друштва преко „методолошког национализма“ до заједница попут хорди од само 40 до 50 људи, као што је то било могуће педесетих година 20. века (Turnbull 1961). Социолошка теорија бави се друштвеношћу у оквиру емпиријских заједница, у распону од глобалног друштва до појединца као основне друштвене јединице „институционализоване“ биографијом (Kohli 1985). Питање да ли друштво можемо да опишемо друштвеним класама, формалним организацијама или поткултурама мора бити решено емпиријски; међутим, питање како ми размишљамо о друштву тиче се концептуалних задатака социолошке теорије.

\footnotetext{
${ }^{19}$ Према Јоасовој и Кнобловој сугестији (Joas \& Knöbl 2004) разликовање социолошке теорије и друштвене теорије се чини корисним. Међутим, њихово виђење друштвене теорије као „леве“ теорије није адекватно.
} 


\section{(в) Дијагнозе савременог друштва}

Будући да, генерално говорећи, социолошка теорија остаје компаративна, дијагноза друштва испитује врло специфичне појаве у одређеном савременом друштву које су емпиријски доступне. Социолошке дијагнозе настоје да истакну специфичне особине по којима се ово посебно савремено друштво разликује од претходних друштава или од других савремених друштава. (Пошто могу брзо да застаре, познате дијагнозе друштава током осамдесетих, попут друштва ризика или друштва знања, морају се посматрати као историјски феномени.) Дијагнозе друштва су повезане са инсинуацијом промене, иновације или револуције (Volkmann 2015: 143). Такву промену, чији смо данас сведоци, називамо „рефигурацијом“, а наша дијагноза односи се на комуникацијско друштво. Иако повезујемо ове дијагнозе са општим разматрањима о судбини модерне, вероватно ћемо по први пут у овом делу књиге ући у подручје у ком се социологија сусреће са интелектуалним дискурсом ван ње и које је окарактерисано као дијагноза нашег времена (Osrecki 2011). Међутим, пошто је ова књига намењена заинтересованој академској публици, а не заинтересованој, али општијој интелектуалној публици, желимо да нагласимо концепт дијагнозе друштва. Као и дијагноза времена уопште, дијагноза друштва наглашава промене на рачун већ постојећих структура и остаје хипотетичка, привремена и прилично непрецизна. ${ }^{21}$ Ипак покушаћемо да идентификујемо низ аналитичких карактеристика трансформације које претпостављамо да ће се десити и које су или назначене емпиријским истраживањем или су изведене из теоријских разматрања. Стога их треба емпиријски проучавати као систематски емпиријски истраживачки програм у оквиру комуникацијског друштва.

Овај основни покушај формулисања теорије комуникативне конструкције већ је део овог истраживачког програма. Ако је тачно да се друштвене науке не могу одвојити од друштва, оне то треба да одражавају и прилагођавањем својих концептуалних апарата променама у друштву. Чак и унутар друштвених наука, комуникацијско друштво је уочљиво, тако да комуникативну конструкцију стварности треба схватити као покушај концептуалног прилагођавања друштвеним променама.

Након ове троструке поделе, у првом делу ове књиге бавићемо се друштвеном теоријом. Аналитички започињемо на микро нивоу комуникативног делања, што више пута илуструјемо примером показивања прстом. Даље анализирамо овај ниво помоћу детаљних концепата које дефинишемо и разликујемо од постојећих теоријских концепата у друштвеној теорији. Овај одељак је прилично апстрактан и, повремено, помало незграпан, али је неопходан да

\footnotetext{
20 Идеја друштвене дијагнозе, која је чак ушла у говорни немачки, није уобичајена у англосаксонском дискурсу. Мајк Севиџ је тек недавно назвао ову врсту аргументационог стила „презентизмом“ (Savage 2009, 2010). Видети и рад Дејвида Инглиса (Inglis 2014).

${ }^{21}$ Према Фридрихсу, Лепсиусу и Majepy (Friedrichs, Lepsius \& Mayer 1998) социолошке дијагнозе се формирају обједињавањем сложеног друштвеног догађаја у изјаву о стању друштва. Дијагноза нашег времена, са друге стране, значи стављање на страну нејасних детаља како бисмо могли дати конкретне изјаве о стању у друштву.
} 
би се концепти сместили у контекст различитих друштвено-научних дискурса и да би се међусобно повезивали на такав начин да се формира веза између концепата, а тиме и теорије. Тек након овог путовања кроз дубине теорије комуникативне конструкције можемо да се окренемо друштвеној структури која је изграђена комуникативним делањем: друштво карактеришу комуникативни облици, структуре и институције који настају из временског и просторног повезивања комуникативних делања у низове. У овом другом делу само испитујемо веома општу друштвену теорију да бисмо омогућили да се она прецизно дефинише у односу на најразличитија емпиријска друштва - од хорди као друштва до изузетно сложених, функционално диференцираних система.

Питање у каквом друштву данас живимо - дијагноза друштва - детаљно се обрађује у трећем делу књиге. Медијатизација комуникативног делања доводи до далекосежних промена које се могу сажети оним што ћемо назвати комуникацијским друштвом.

са енглеског језика превели: Марија Хаџи Милић и Милош Јовановић стручна редакција на основу немачког изворника: Душан Ристић и Милош Јовановић

\section{Референце}

Beer, T., H. Bleses \& S. Ziegler. (2015) "Personen mit Demenz und robotische Assistenzsysteme". Plege \& Gesellschat 20: 20-36.

Berger, P. L. (1971) Einladung zur Soziologie: Eine humanistische Perspektive. München: List.

Bhambra, G. K. (2014) Connected Sociologies. London: Bloomsbury.

Bourdieu, P. (2001) Science de la science et rélexivité. Paris: Raisons d'agir.

Burawoy, M. (2005) “For Public Sociology”. American Sociological Review 70: 4-28.

Buschinger, A. (1985) Staatenbildung der Insekten. Darmstadt: Wissenschaftliche Buchgesellschaft.

Chakrabarty, D. (2010) Europa als Provinz: Perspektiven postkolonialer Geschichtsschreibung. Frankfurt am Main: Campus Verlag.

Eisenstadt, S. N. (2002) Multiple Modernities. Edison NJ: Transaction.

Elliott, A. (2009) Contemporary Social Theory: An Introduction. London und New York: Routledge.

Endreß, M. (2002) Formation und Transformation sozialer Wirklichkeit. Eine Untersuchung zur phänomenologisch begründeten Soziologie und Sozialtheorie. Tübingen: Habilitationsschrift.

Friedrichs, J., K. U. Mayer \& M. R. Lepsius (Hrsg.) (1998) Die Diagnosefähigkeit der Soziologie. Kölner Zeitschrit für Soziologie und Sozialpsychologie, Sonderhet 38. Opladen: Westdeutscher Verlag. 
Giddens, A. (1984) The Constitution of Society: Outline of the Theory of Structuration. Cambridge: Polity Press.

Görtz, H.-D. (1988) Formen des Zusammenlebens: Symbiose, Parasitismus und andere Vergesellschaftungen von Tieren. Darmstadt: Wissenschatliche Buchgesellschaft.

Habermas, J. \& J. Ratzinger. (2006) The Dialectics of Secularization: On Reason and Religion. San Francisco: Ignatius Press.

Hannappel, H. \& H. Melenk. (1979) Alltagssprache: Semantische Grundbegriffe und Analysebeispiele. München: Fink.

Inglis, D. (2014) "What is Worth Defending in Sociology Today? Presentism, Historical Vision and the Uses of Sociology". Cultural Sociology 8(1): 99-118.

Joas, H. \& W. Knöbl. (2004) Sozialtheorie: Zwanzig einführende Vorlesungen. Frankfurt am Main: Suhrkamp.

Kamlah, W. \& P. Lorenzen. (1967) Logische Propädeutik: Vorschule des vernünftigen Redens. Mannheim: Bibliographisches Institut.

Katz, J. (2001) “Analytic Induction", in International Encyclopedia of the Social \& Behavioral Sciences (N. J. Smelser \& P. B. Baltes eds.), 480-484. Elsevier.

Keller, R. (2014) “Zukünte der qualitativen Sozialforschung”, in Qualitative Forschung (Günter Mey \& Katja Mruck eds.), 167-180. Wiesbaden: Springer VS.

Knoblauch, H. (2013) "Grundbegrife und Aufgaben des kommunikativen Konstruktivismus", in Kommunikativer Konstruktivismus (R. Keller, J. Reichertz \& H. Knoblauch eds.), 25-48. Wiesbaden: Springer VS.

Knoblauch, H. \& R. Wilke. (2016) "The Common Denominator: The Reception and Impact of Berger and Luckmann's The Social Construction of Reality". Human Studies 39: 51-69.

Kohli, M. (1985) "Die Institutionalisierung des Lebenslaufs. Historische Befunde und theoretische Argumente". Kölner Zeitschrift für Soziologie und Sozialpsychologie 37: $1-29$.

Latour, B. (2001) Das Parlament der Dinge. Für eine politische Ökologie. Frankfurt am Main: Suhrkamp.

Latour, B. \& S. Woolgar. (1979) Laboratory Life: The Social Construction of Scientific Facts. Beverly Hills: Sage Publications.

Lindemann, G. (2002) Die Grenzen des Sozialen: Zur sozio-technischen Konstruktion von Leben und Tod in der Intensivmedizin. München: Fink.

Lindemann, G. (2009) Das Soziale von seinen Grenzen her denken. Weilerswist: Velbrück Wissenschaft.

Lindemann, G. (2014) Weltzugänge: Die mehrdimensionale Ordnung des Sozialen. Weilerswist: Velbrück Wissenschaft.

Luhmann, N. (1980) Gesellschaftsstruktur und Semantik: Studien zur Wissenssoziologie der modernen Gesellschaft, Bd. 1. Frankfurt am Main: Suhrkamp.

Marchart, O. (2013) Das unmögliche Objekt: Eine postfundamentalistische Theorie der Gesellschaft. Berlin: Suhrkamp.

Meidl, C. N. (2009) Wissenschaftstheorien für SozialforscherInnen. Wien: Böhlau. 
Merton, R. K. (1949) Social Theory and Social Structure: Toward the Codification of Theory and Research. Glencoe: Free Press.

Osrecki, F. (2011) Die Diagnosegesellschaft: Zeitdiagnostik zwischen Soziologie und medialer Popularität. Bielefeld: Transcript.

Savage, M. (2009) "Against epochalism: An analysis of conceptions of change in British sociology”. Cultural Sociology 3(2): 217-238.

Savage, M. (2010) “Unpicking sociology's misfortunes”. The British Journal of Sociology 61(4): 659-665.

Seidman, S. (2004) Contested Knowledge. Social Theory Today. Oxford: Blackwell.

Turnbull, C. M. (1961) The Forest People. New York: Simon and Schuster.

Volkmann, U. (2015) "Soziologische Zeitdiagnostik. Eine wissenssoziologische Ortsbestimmung”. Soziologie 44: 139-152. 
